\title{
The Effect of Heat Curing Methods on the Protection against Frost Damage at Early Age of the Concrete Under Extremely Cold Climate
}

\author{
Jung, Eun-Bong ${ }^{1} \quad$ Shin, Hyun-Sup ${ }^{2} \quad$ Han, Min-Cheol ${ }^{3^{*}}$ \\ Department of Architectural Engineering, Cheong-Ju University, Sangdang-Gu, Cheong-Ju, 360-710, Korea ${ }^{1}$ \\ Lafarge Halla Cement Sales Division Jungbu Office, 2-dong, Ui-Wang, 437-030, Korea ${ }^{2}$ \\ Department of Architectural Engineering, Cheong-Ju University, Sangdang-Gu, Cheong-Ju, 360-710, Korea ${ }^{3}$
}

\section{Abstract}

This study aimed to examine whether heat curing methods of concrete subjected to $-10^{\circ} \mathrm{C}$ could be effective by varying the combination of heating cable and surface heat insulations. Three different concrete specimens incorporating $30 \%$ fly ash with $50 \% \mathrm{~W} / \mathrm{B}$ were fabricated to simulate wall, column and slab members with dimensions of $1600 \times 800 \times 200 \mathrm{~mm}$ for slab, $800 \times 600 \times 200 \mathrm{~mm}$ for wall and $800 \times 800 \times 800 \mathrm{~mm}$ for column. For heat curing combinations, Type -1 specimens applied PE film for slab, plywood for wall and column curing. Type- 2 specimens applied double layer bubble sheet (2LB) and heating coil for slab, and $50 \mathrm{~mm}$ styrofoam for wall and column curing. Type- 3 specimen applied 2LB for slab, electrical heating mat for wall and column inside heating enclosure. The test results revealed that the temperature of Type 1 specimen dropped below $0^{\circ} \mathrm{C}$ beginning at 48 hours after placement due to its poor heat insulating capability. Type 2 and 3 specimens maintained a temperature of around $5 \sim 10^{\circ} \mathrm{C}$ after placement due to favorable heat insulating and thermal resistance.

Keywords : low temperature, curing method, frost damage at early age, temperature history, strength development

\section{Introduction}

With pressure to reduce the cost and duration of construction on the rise at construction sites, there has been a keen interest taken in the optimization of construction of the reinforced concrete framework.

Notably, in relation to reducing construction duration, year-round construction activities have been promoted as a main approach, but many construction sites stop concrete construction when the daily average temperature is below zero, lose the opportunity to reduce construction duration

\section{Received : April 19, 2013}

Revision received : September 13, 2013

Accepted : October 1, 2013

* Corresponding author : Han, Min-Cheol [Tel: 82-43-229-8484, E-mail: twhan@cju.ac.kr]

(c)2013 The Korea Institute of Building Construction, All rights reserved. due to flimsy curing facilities and insufficient heating and warming measures, or suffer from damage to concrete due to freezing at early age.

However, when heat curing is applied to prevent damage to concrete due to freezing at early age, it is known to reduce the construction duration even in cold weather, and improve concrete quality positively as well; as such, it has been widely used in advanced countries, including Japan[1,2,3]. Magnus proposed a method for construction in cold weather using an air-inflated membrane structure to install a provisional curing facility in a windy and snowy area[4]. In addition, Fukai et al. reported the test results on the use of a sheet with an embedded heating coil to prevent freezing at early age[5], Peker et al. studied concrete placed in Alaska and obtained satisfactory results by using adjustment 
to mix proportion and heating coil in an area where temperature is lower than $-20^{\circ} \mathrm{C}[6]$.

On the other hand, looking at studies on construction in cold weather, Han et al. developed an insulation curing method using bubble sheet, and reported that it was effective for preventing the freezing of slab members at early age as low as $-10^{\circ} \mathrm{C} .[7,8]$.

However, few studies have been conducted on an insulation curing method for outdoor conditions with a daily average temperature of $-10^{\circ} \mathrm{Cor}$ lower to effectively prevent freezing at early age and secure constructability and economy. The insulation curing methods currently in use can cause increased cost and insufficient quality, and thus an insulation curing method appropriate for cold spell weather conditions should be developed.

Thus, to propose an effective method of preventing concrete freezing at early ages we manufactured an integrated miniature with columns, walls and slabs, used a different insulation curing method for each member, and analyzed the impact of the members on the temperature history of concrete and strength development.

\section{Experiment plan and methodology}

\subsection{Experiment plan}

The experiment plan for this study is indicated in Table 1, and the mix proportion is in Table 2. First of all, the experimental factors are W/B, slump and air content, the proportions of which were applied as is in the field, and to simulate an extremely low temperature condition the internal temperature of the curing chamber was set at a constant temperature of $-10^{\circ} \mathrm{C}$. As shown in Figures 2 and 3, the concrete members for this experiment were manufactured by combining slabs, walls and columns into one. The dimensions of each component were $1600 \times 800 \times 200 \mathrm{~mm}$ for the slab, $800 \times 600 \times 200 \mathrm{~mm}$ for the wall, and $800 \times 800 \times 800 \mathrm{~mm}$ for the column.

An insulation curing method to prevent freezing at early ages that showed the optimal results in the laboratory experiment was applied[9,10].

Table 1. Experimental plan

\begin{tabular}{|c|c|c|}
\hline & Factors & Levels \\
\hline \multirow{3}{*}{ Mixture } & W/B (\%) & 50 \\
\hline & Target slump (mm) & $150 \pm 15$ \\
\hline & Air contents (\%) & $4.5 \pm 1.5$ \\
\hline \multirow{3}{*}{$\begin{array}{l}\text { Experiment } \\
\text { variable }\end{array}$} & $\begin{array}{l}\text { Curing temperature } \\
\qquad\left({ }^{\circ} \mathrm{C}\right)\end{array}$ & -10 \\
\hline & Curing periods & $\begin{array}{l}\text { - Initial curing : } 7 \text { days } \\
\text { - Subsequent curing : } 3 \text { days }\end{array}$ \\
\hline & Type of member & - Slab+Wall+Column \\
\hline \multirow{2}{*}{ Experiment } & Fresh concrete & $\begin{array}{l}\text { - Slump } \\
\text { - Air contents }\end{array}$ \\
\hline & Hardened concrete & $\begin{array}{l}\text { - Temperature history } \\
\text { - Core strength ( } 28 \text { days) }\end{array}$ \\
\hline
\end{tabular}

Table 2. Mix proportion of the concrete

\begin{tabular}{ccccccccccc}
\hline Strength & $\mathrm{G}_{\operatorname{Max}}$ & W/B & $\mathrm{S} / \mathrm{a}$ & \multicolumn{1}{c}{ Weight $\left(\mathrm{kg} / \mathrm{m}^{3}\right)$} \\
$\mathrm{MPa}$ & $\mathrm{mm}$ & $\%$ & $\%$ & W & $\mathrm{C}$ & FA & $\mathrm{G}$ & $\mathrm{S}$ & WRA & AEA \\
\hline 28 & 19.05 & 50 & 46.7 & 162 & 260 & 64 & 938 & 822 & 2.083 & 0.208 \\
\hline
\end{tabular}

As presented in Table 3, three types of control specimens were planned: a combination of slab(PE film)+wall(plywood)+column(plywood) (Type 1), a combination of slab(double-layered bubble sheet+heating coil)+column(insulation)+column(insulation)(Type 2), and a combination of slab(double-layered bubble sheet+lower part heating)+wall(heating mat)+column(heating mat). The temperature history by part and the compressive strength of the core specimen were measured in the experiment.

\subsection{Curing method}

Table 3 indicates the curing method used in this study. First of all, to prevent freezing at early age, the initial curing was planned to be 7 days 
based on the test results, after the initial curing to prevent cracks caused by the impact of temperature the concrete was continuously cured for 3 more days. Subsequently, the concrete was exposed to an outside temperature of $-10^{\circ} \mathrm{C}$ for 18 days. A total of 28 days of curing was planned.

Table 3. Heat curing methods

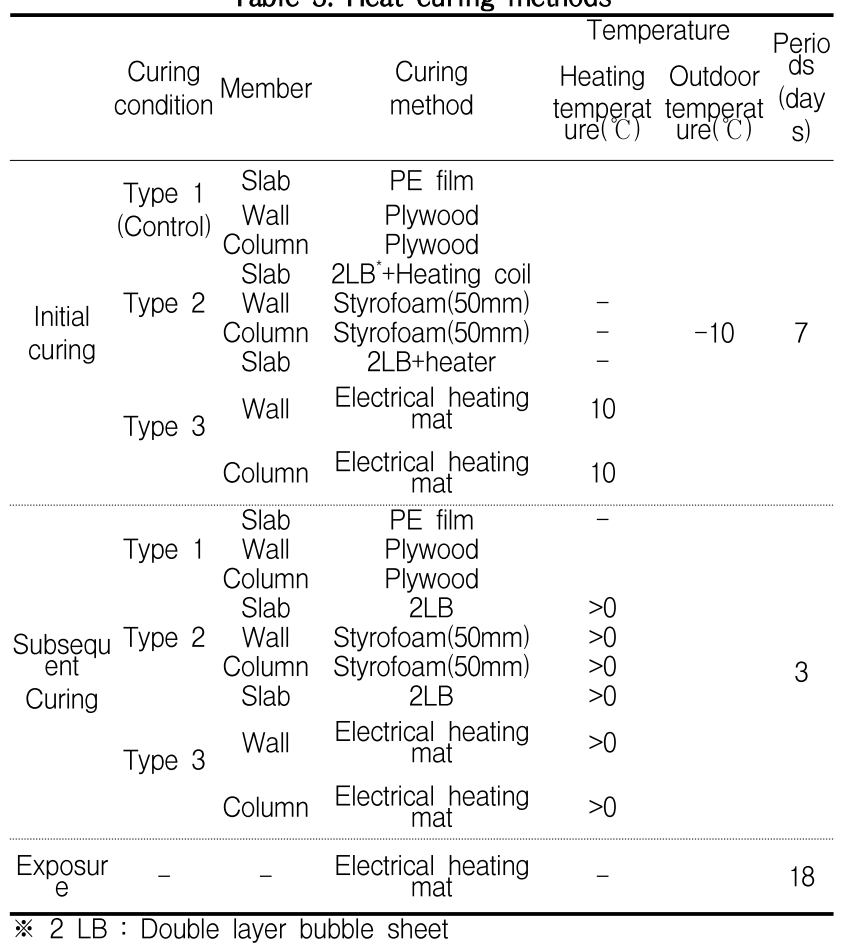

\subsection{Used materials}

Of surface curing materials, commercial double-layered bubble sheet was used, and commercial heating coil was also used for the concrete embedment. The physical properties of each material are indicated in Figure 1 and Tables 4 and 5.
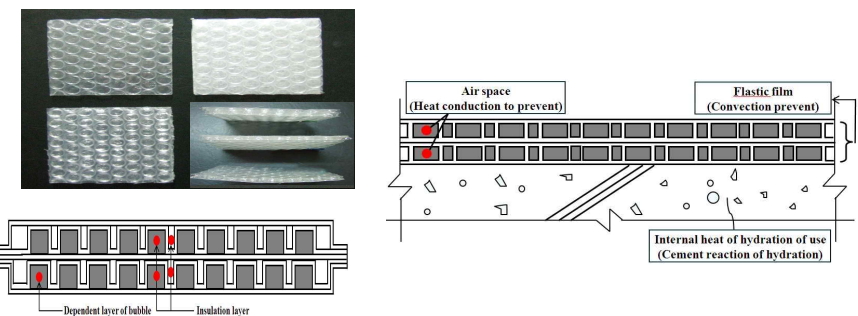

Figure 1. Section details of a bubble sheet covering the concrete surface
Table 4. Physical properties of bubble sheet

\begin{tabular}{cccc}
\hline $\begin{array}{c}\text { Surface curing } \\
\text { material }\end{array}$ & $\begin{array}{c}\text { Thickness } \\
(\mathrm{mm})\end{array}$ & $\begin{array}{c}\text { Air-cell } \\
\text { volume } \\
(\mathrm{mm})\end{array}$ & $\begin{array}{c}\text { Heat } \\
\text { conduction } \\
(\mathrm{W} / \mathrm{m} \cdot \mathrm{K})\end{array}$ \\
\hline $\begin{array}{c}\text { Double layered } \\
\text { bubble sheet (2LB) }\end{array}$ & 3 & 7 & 0.03 \\
\hline
\end{tabular}

Table 5. Physical properties of heating cable

\begin{tabular}{cccc}
\hline Image & $\begin{array}{c}\text { Diameter } \\
(\mathrm{mm})\end{array}$ & $\begin{array}{c}\text { Power } \\
\text { consumption } \\
(\mathrm{W})\end{array}$ & $\begin{array}{c}\text { Maximum heat } \\
\text { temperature }\left({ }^{\circ} \mathrm{C}\right)\end{array}$ \\
\hline 10 & $1 \sim 3$ & 20 & 50 \\
\hline
\end{tabular}

\subsection{Experiment method}

1) Insulation curing at temperature condition of $-10^{\circ} \mathrm{C}$ (Types 1 and 2)

Mock-up member was assumed as part of the 200mm-thick slab shown in Figure 2 (a) and (b) and manufactured in the dimensions of $1600 \times 800 \times 200 \mathrm{~mm}$, the wall member in the dimensions of $800 \times 600 \times 200 \mathrm{~mm}$ and the column member in the dimensions of $800 \times 800 \times 800 \mathrm{~mm}$. These were then cured by applying the curing method shown in Table 3.

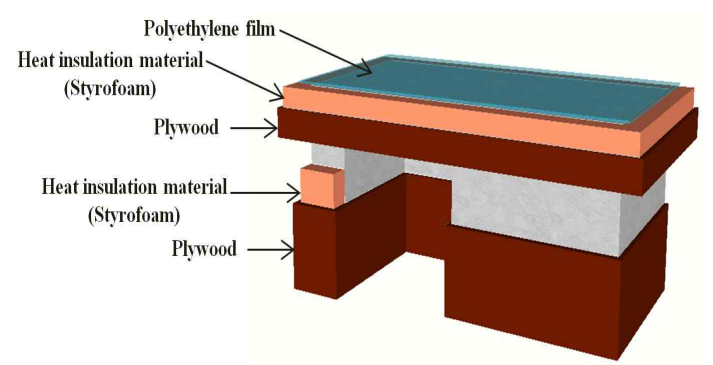

(a) Slab(PE film)+Wall(Plywood form)+column(Plywood form)-(Type 1)

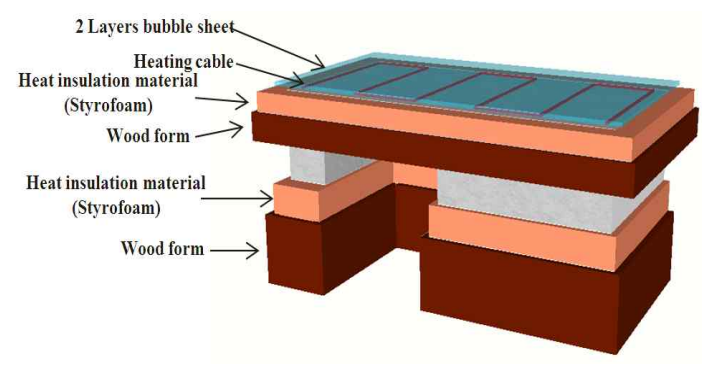

(b)Slab(2LB+heating

cable)+Wall(Styrofoam)+column(Styrofoam)-(Type2)

Figure 2. Preparation of mock-up specimen and curing method 


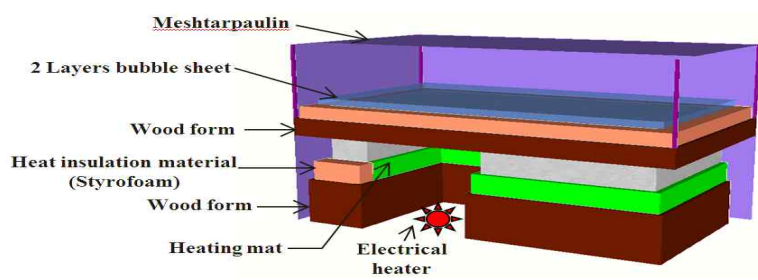

Figure 3. Slab(2LB+electrical heater)+Wall(Heating mat) + column(Heating mat) - (Type 3)

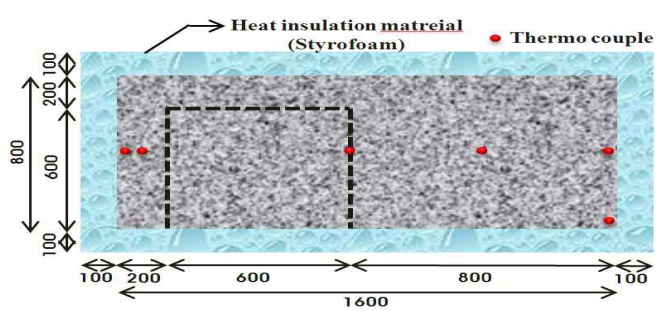

(a) Location of $\mathrm{T}$ type thermocouple (slab member)

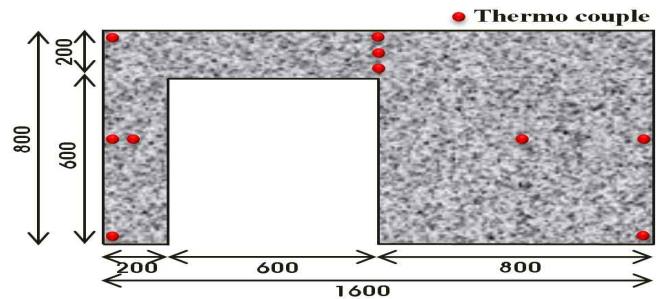

(b) Location of $\mathrm{T}$ type thermocouple (wall and column member)

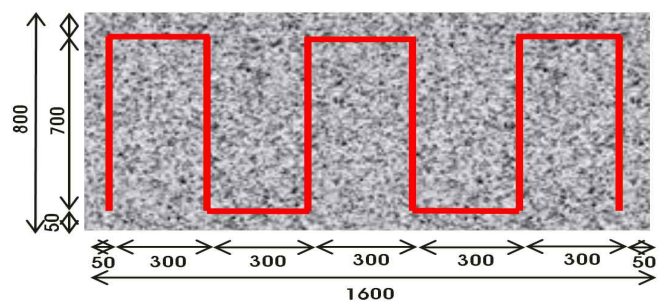

(c) Heating cable arrangement

Figure 4. Installation of thermocouple and heating cable arrangement

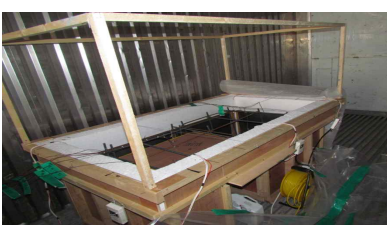

(a) Form work preparation

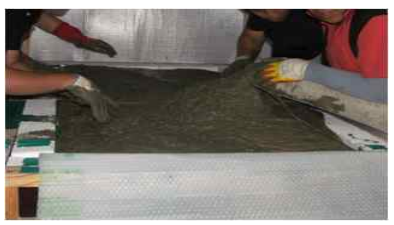

(c) Concrete pouring

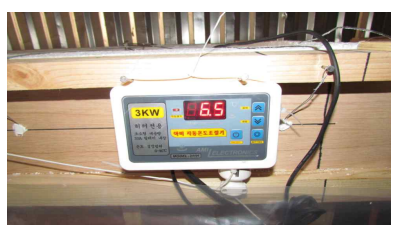

(b) Heating cable thermostat

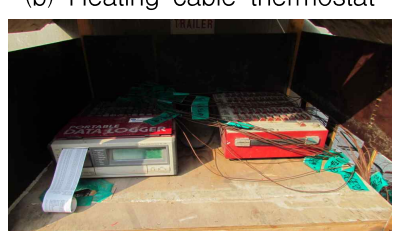

(d) Measuring temperature
Figure 5. Mock-up concrete pouring and temperature history measurement
2) Composite curing under $-10^{\circ} \mathrm{C}$ temperature condition (Type 3)

The mock-up member spatially heated is illustrated in Figure 3, the curing chambers were installed in the upper and lower parts of the member, and insulation curing was implemented after wrapping with mesh tarpaulin. Space was prepared for heating the lower part of the member with a 1000W electric heater.

As shown in Figure 4 (a) and (b), the temperature was measured in the upper part, in the middle part and in the lower part, and T-type thermal couples were embedded at the corners to measure the temperature history of the inner concrete using a data logger. A heating coil for heating coil curing was installed $50 \mathrm{~mm}$ under the concrete' s surface with an interval of $250 \mathrm{~mm}$ as shown in Figure 4(c), and fed power for the curing period to maintain the temperature at $10^{\circ} \mathrm{C}$.

\section{Test results and analysis}

\subsection{Characteristics of the temperature history by insulation curing method}

Figure 6 shows the temperature history in the upper part, in the middle part, in the lower part and on the surface.

First of all, it was found in the slab that the temperature rapidly dropped after concrete placement due to the insufficient insulation performance of the PE film, and around 36 hours after placement the temperature dropped below zero and approached the outside temperature of $-10^{\circ} \mathrm{C}$. It was found in the wall and column that plywood form was applied without any other insulation, and around 48 hours after placement the temperature dropped below zero and approached the outside temperature of $-10^{\circ} \mathrm{C}$. Therefore, when no other insulation was provided under the outside temper- 
ature condition of $-10^{\circ} \mathrm{C}$, the temperature dropped below zero within 1 or 2 days after the concrete placement, which brings a high possibility of freezing at early stages.
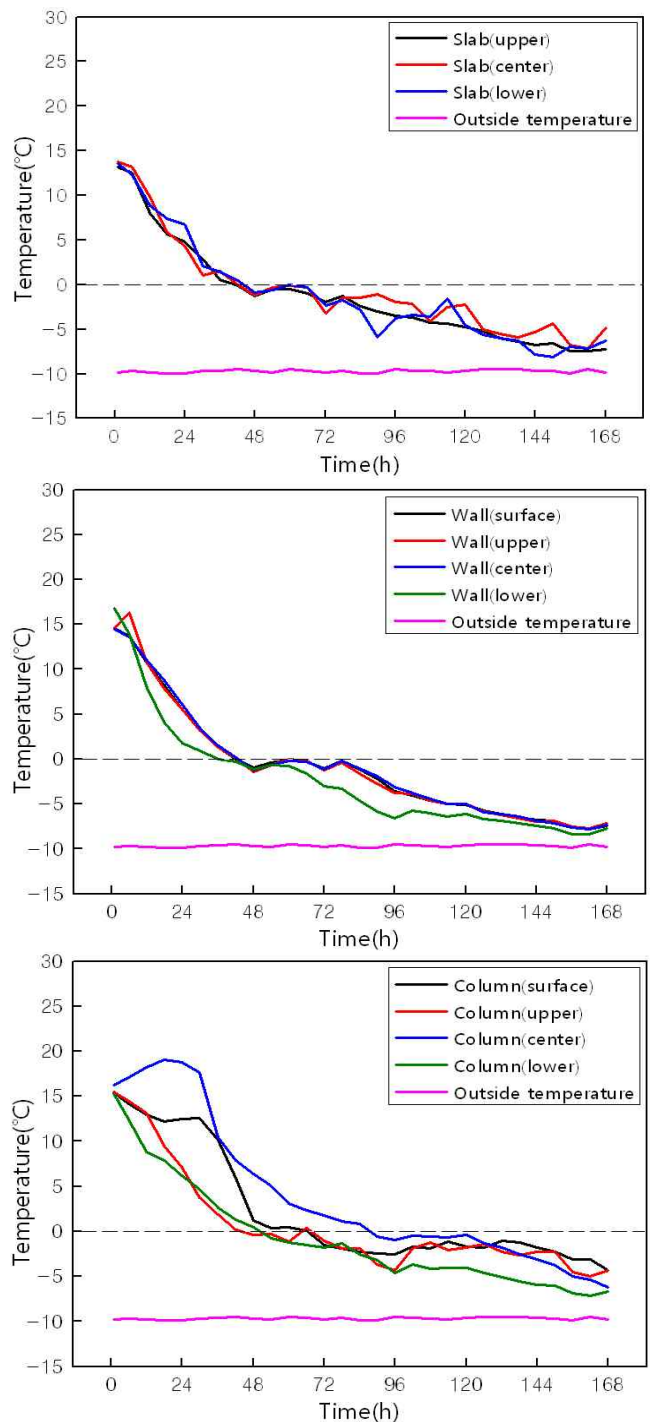

Figure 6. Temperature history of the Type 1 specimen

On the other hand, Figure 7 illustrates the temperature history of Type 2 specimen with slab(heating coil+2LB)+wall(50mm-thick Styrofoam)+column (50mm-think Styrofoam) applied. First, it was found in the slab that the temperature dropped gradually, and around 60 hours after the cement' s placement the temperature dropped around zero, but the temperature was maintained at
$10 \sim 15^{\circ} \mathrm{C}$ in all parts of the specimen due to the continuous supply of heat from the heating coil, from which it was discovered that the combination of heating coil+2LB had satisfactory insulation and rapid heating effect. On the other hand, it was found in the wall and the lower part of the column that 50mm-thick Styrofoam did not have sufficient heat resistance under the $-10^{\circ} \mathrm{C}$ temperature condition, and to prevent a temperature drop, a material that has better insulation performance should be used.
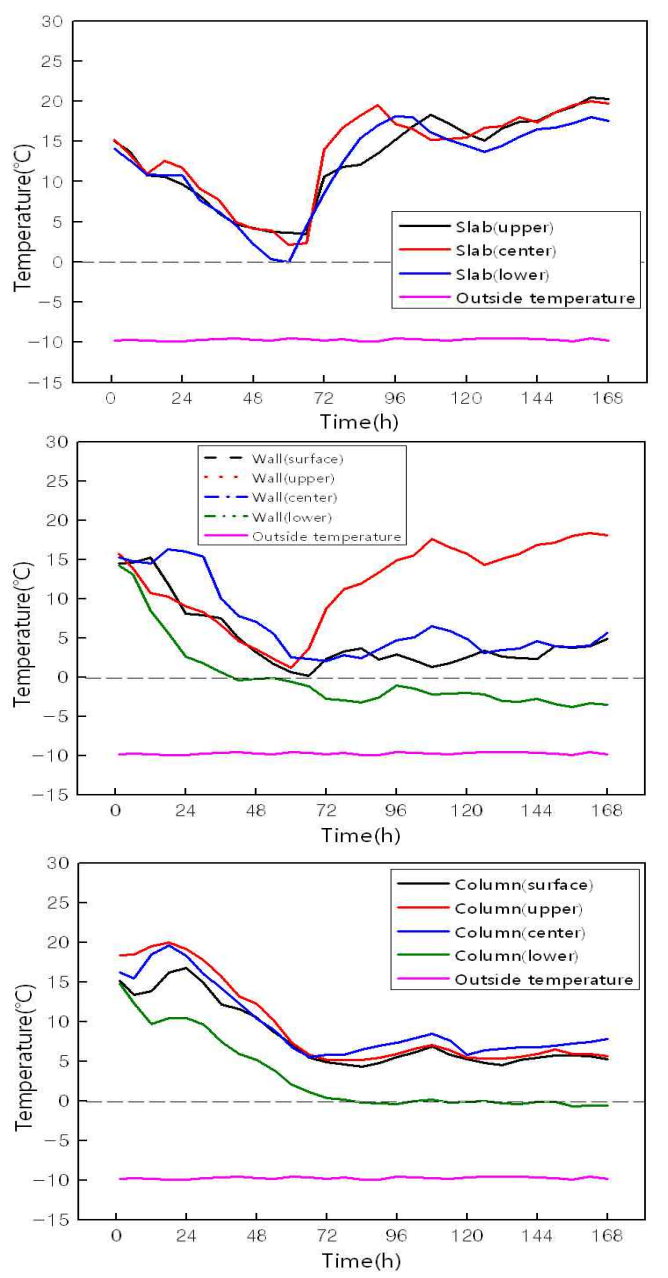

Figure 7. Temperature history of the Type 2 specimen

Figure 8 shows the temperature history of Type 3 after the curing chambers were installed in the upper and the lower parts of the specimen and 
then it was heated. Overall, it was found in slab, wall and column that heat was supplied by the lower part heating and electrical heating mat. While no heat loss to the outside was found after the concrete placement, the temperature dropped due to hydration, but was kept between $5{ }^{\circ} \mathrm{C}$ and $10^{\circ} \mathrm{C}$. Therefore, Type 3 , a combination of spatial heating and insulation, was found to have the best thermal performance of all types.
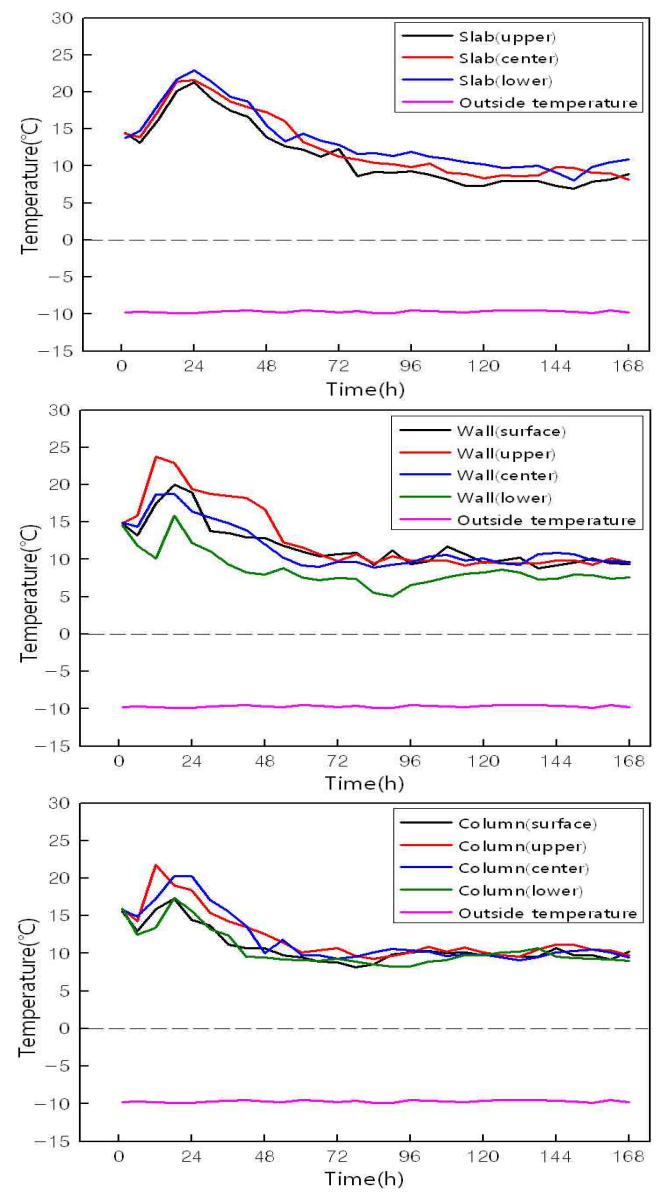

Figure 8. Temperature history of Type 3 specimen

\subsection{Accumulated temperature characteristics according to insulation curing}

As a measure of cold weather concrete freezing at early ages, a method to consider accumulated temperature is used. Figures 9 through 11 show the conversion into the accumulated temperature of the temperature history of specimen according to insulation curing with the passage of time (see Equation (1)). In relation with this, according to Cold Weather Concrete in the Construction Guide of the Architectural Institute of Japan[11], the accumulated temperature of $45^{\circ} \mathrm{D} \cdot \mathrm{D}$ or higher is recommended to develop the compressive strength of $5 \mathrm{MPa}$, which helps prevent fly ash-mixed concrete from freezing at early ages under low temperature conditions.

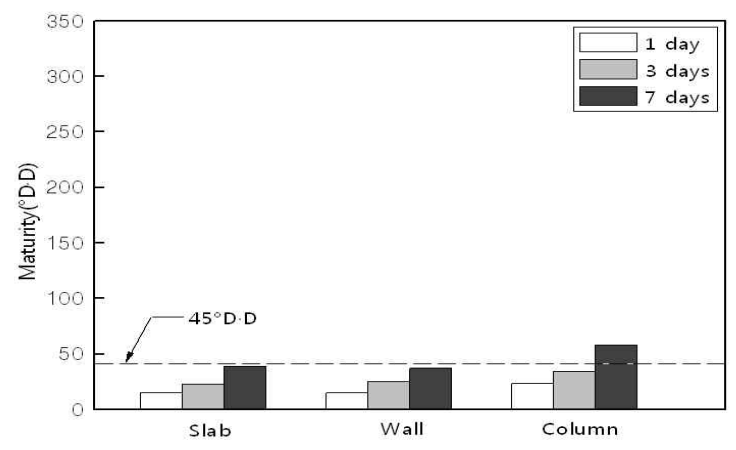

Figure 9. Maturity development with age (Type 1)

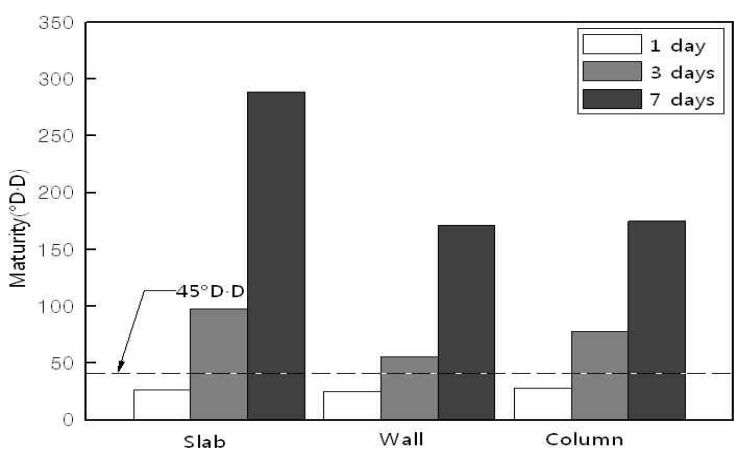

Figure 10. Maturity development with age (Type 2)

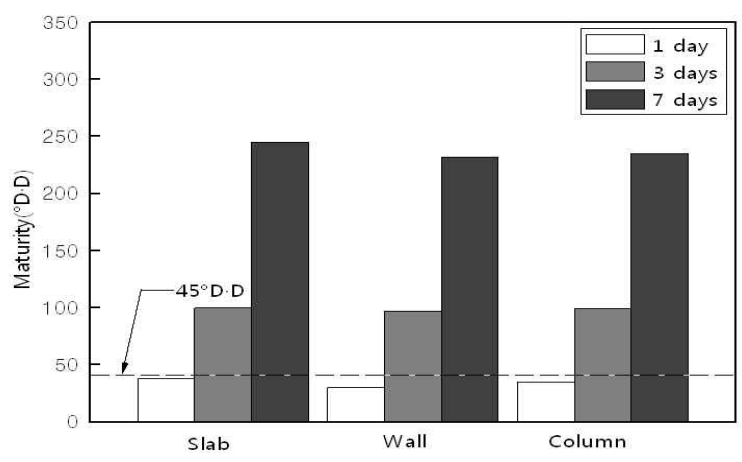

Figure 11. Maturity development with age (Type 3) 
The accumulated temperature with the passage of time was measured in all parts except the column at $45^{\circ} \mathrm{D} \cdot \mathrm{D}$ or lower in Type 1 up to 7 days because of its insufficient insulation, and the temperature history during this period was shown as below zero, based on which it may have a high possibility of freezing at early age. In Type 2, sufficient heat was supplied by the combination of heating coil and insulation curing so that the accumulated temperature required to prevent freezing at early ages was reached in slab, wall and column around 3 days after the placement. In addition, in Type 3 where spatial heating was implemented, the temperature history was shown to be the highest among all the specimen types, and the accumulated temperature required to prevent the freezing at early ages was reached before 3 days after the placement, and at 3 days its accumulated temperature was secured as $100^{\circ} \mathrm{D} \cdot \mathrm{D}$ or higher, which is the highest of all.

$$
M=\sum_{0}^{t}\left(\theta_{z}+10\right) \Delta t
$$

Here, $\theta \mathrm{z}:$ curing temperature $\left({ }^{\circ} \mathrm{C}\right), \Delta \mathrm{t}:$ peri-

$$
\text { od(days) }
$$

Therefore, it is desirable that when focusing on reduction in construction duration at construction sites, a high accumulated temperature should be secured at early age, but when focusing on reduction in construction cost the insulation curing should be considered.

\subsection{Strength development characteristics according to insulation curing}

1) Compressive strength development of core specimen

First, the compressive strength of the standard cured specimen was 29.7Mpa at 29 days, which meets the target requirements for strength.

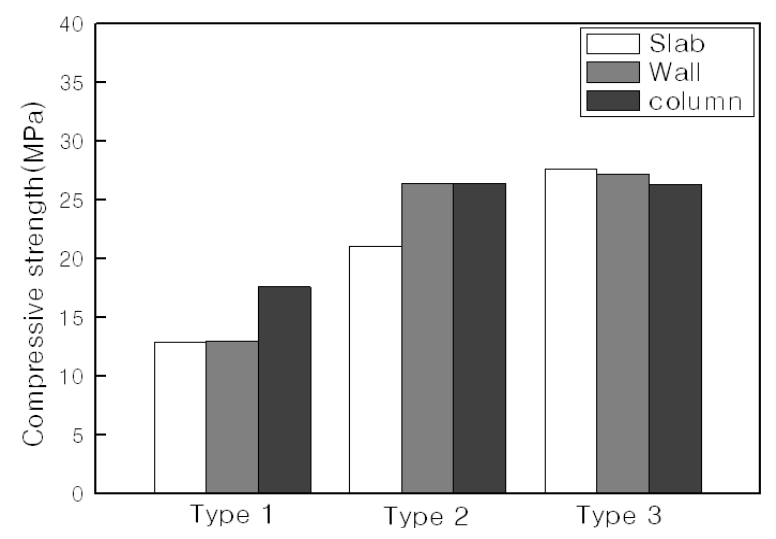

Figure 12. Core compressive strength at 28 days

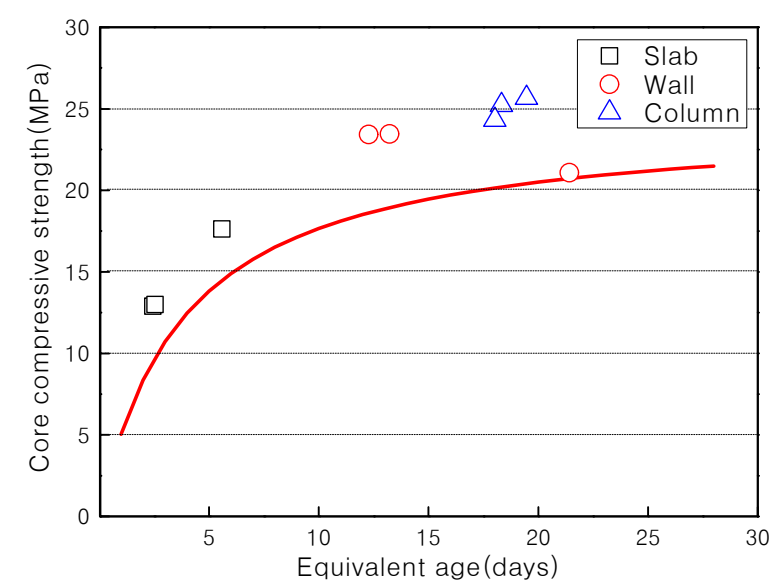

Figure 13. Relationship between core strength and maturity

On the other hand, Figure 12 shows the core compressive strength according to the curing method at 28 days under $-10^{\circ} \mathrm{C}$ temperature condition. First, the Type 1 specimen on which no insulation measures were taken did not meet the target strength due to its insufficient insulation curing, as identified with the accumulated temperature. On the other hand, the Type 2 specimen in which heating coil was embedded and cured and Type 3 specimen both under which heating was applied and on which electrical heating mat was used showed relatively higher compressive strength compared with that of Type 1 specimen. However, no specimens satisfied the target strength, which is believed to indicate that strength could not be developed fully after 7 days 
because they were exposed to $-10^{\circ} \mathrm{C}$ temperature condition. Therefore, to secure the target strength at target age, additional insulation curing is needed, but this has a direct relation with increased construction cost and duration, and thus measures should be taken in consideration of field conditions.

Figure 13 shows the results of an analysis of strength development with the passage of equivalent age of Gompertz model equation (Equation(2)). The value obtained through a laboratory experiment under the conventional mix condition was used as the experiment constant in the model equation[12,13]. Overall, the analytical results obtained by converting the accumulated temperature into equivalent age were slightly lower than the core strengths measured.

$$
F_{c}=20.4 \exp \left(-1.96\left(\frac{1}{t_{e q}}\right)^{0.73}\right)
$$

Here, $\mathrm{F}_{\mathrm{c}}$ : Compressive strength

teq : equivalent age(days@ $\left.20^{\circ} \mathrm{C}\right)$

Here,

$$
t_{e q}=\int_{0}^{t} \exp \left(\frac{E_{a}}{R} \cdot\left(\frac{1}{T r}-\frac{1}{T}\right)\right) d t
$$

\section{Conclusion}

This study examined the freezing prevention effects of different insulation methods on concrete at early ages under cold weather conditions, and the results are summarized as follows:

1) In terms of the temperature history according to the insulation curing method, it was found in Type 1 that the temperature dropped below zero about 36 to 48 hours after the cement placement due to its insufficient insulation, and approached the outside temperature condition of $-10^{\circ} \mathrm{C}$. On the other hand, it was found in Types 2 and 3, where insulation or heat curing were combined, that the temperature dropped for a while after the cement placement, but room temperature was secured in all parts of those specimens except the lower corner surface of the wall and column of Type 2.

2) The accumulated temperature of Type 1 did not reach the $45^{\circ} \mathrm{D} \cdot \mathrm{D}$ required to prevent freezing at early ages even at 7 days, while the accumulated temperature of Types 2 and 3 where lower part heating was done through heating coil and curing chambers and a heat mat was used reached over $45^{\circ} \mathrm{D} \cdot \mathrm{D}$ at 3 days, and it is believed that freezing at early ages could be prevented in those specimens because the compressive strength was developed early.

3) In terms of the compressive strength of core specimens, the strength development was retarded overall in the specimens where no insulation was applied, and it failed to secure target strength at 28 days. However, the specimen on which heating coil curing and spatial heating were applied approached the target strength at 28 days when a double-layered bubble sheet was also used.

In essence, when heating coil and spatial heating for slab and insulation and electrical heating mat for wall are used to perform effective insulation curing with outside temperature conditions of -1 $0^{\circ} \mathrm{C}$, freezing at early age, the most pressing problem in cold weather concrete construction, can be resolved. Taking economy and constructability into account, effective insulation curing can also be possible when double-layered bubble sheet and heating coil are used together under temperature conditions of $-10^{\circ} \mathrm{C}$. 


\section{Acknowledgement}

This research was partially supported by the Cheong-ju University research scholarship grants in 2012

\section{References}

1. Korhonen CJ. Antifreeze admixtures for cold regions concreting : a literature review. Special Report No. SR 90-32, Hanover, N.H., 1990 Sept;14

2. Korhonen CJ, Cortez ER. Antifreeze admixtures for cold weather concreting. Concrete International. 1991 Mar;13(3):38-41.

3. Damron Floyd J. Design/construction consideration for subarctic wastewater plant, Journal of Cold Regions Engineering. ASCE, 1987 Sept;1(3):133-44.

4. Alfred R. Mangus. Air structure protection of cold weather concreting. Concrete International. 1988 Oct;10(10):22-6.

5. Fukai A, Sugiyama M. Application and Research of the Housing Base Concrete to the Curing Using New Heating Sheet. ACI Special Publication. 2006 Sep;1(235):257-68.

6. Pekar JW. Concreting in alaska. Concrete International. 1988 Oct:10(10):28-30.

7. Han OG, Han MC, Baek DH. Analysis on the heat insulation performance of cold weather concrete according to change of laid construction conditions of double bubble sheets. Journal of Korea Institute of Building Construction, 2010 Dec;10(5):121-9.

8. Han CG, Han MC, Baek DH, Son HJ, Hong SM. Temperature history of concrete according to the covering method of double layer bubble sheet. Proceeding of Korea Institute of Building Construction; 2010 May; Seou l(Korea). Seoul (Korea): Korea Institute of Building Construction; 2010. p. $71-2$.

9. Han OG, Han MC, Koh KT, Ahn SK, Jung SH, Han SY, Temperature history of the slab concrete subjected to $-10^{\circ} \mathrm{C}$ depending on the combination of heating cable and insulation heat curing, Proc. of Korea Concrete Institute, 2011 Nov; Seoul (Korea). Pyeong Chang (Korea): Korea Concrete Institute; 2011. p. 407-8.

10. Lee GC, Han MC, Baek DH, Koh KT. Effect of heat curing method on the temperature history and strength development of slab concrete for nuclear power plant structures in cold climates. Journal of Korean Nuclear Society. 2012;44(5):523-34.
11. Architectural Institute of Japanese. Recommendation for Practice cold weather concreting. 1st ed. Tokyo (Japan): Architectural Institute of Japanese; 2010. 359 p.

12. Han MC. Estimation of compressive strength of the fly ash substitution cement mortar by equivalent age. Journal of Korean Recycled Construction Resources Institute. 2012 Dec;7(4):121-7.

13. Han MC, Son HJ. The effect of heat curing method on the temperature history of the fly ash concrete subjected to extremely low temperature. Journal of Korean Recycled Construction Resources Institute. 2012 Sep;7(3):85-90. 